\title{
Revised Distribution Method of finding Optimal Solution for Transportation Problems
}

\author{
S. Aramuthakannan ${ }^{1}$, Dr.P.R Kandasamy ${ }^{2}$ \\ ${ }^{1}$ Research Scholar, Karpagam University, Coimbatore, Tamilnadu, India \\ ${ }^{2}$ Director, Computer Applications, Hindusthan Institute of Technology, Coimbatore, Tamilnadu, India
}

\begin{abstract}
Transportation problem is a special type of linear programming problem. This paper introduce a new approach to transportation problem namely, Revised Distribution method (RDI), for solving a wide range of such problems. The new method is based on allocating units to the cells in the transportation matrix starting with minimum demand or supply to the cell with minimum cost in the transportation matrix and then try to find an optimum solution to the given transportation problem. The proposed method is a systematic procedure, easy to apply and can be utilized for all types of Transportation problem with maximize or minimize objective functions. At the end, this method is illustrated with some numerical example.
\end{abstract}

Keywords: Transportation problem, Linear programming Problem, MODI method

\section{Introduction}

An important topic, put forward immediately after the Linear programming problem [1], is the transportation problem. This is particularly important in the theory of decision making. The transportation problem is one of the earliest applications of linear programming problem. Different methods have been presented for Transportation problem and various articles have been published on the subject.

In this problem we determine optimal shipping patterns between origins or sources and destinations [5]. Many problems which have nothing to do with transportation have this structure. Suppose that $m$ origins are to supply $n$ destinations with a certain product. Let $a_{i}$ be the amount of the product available at origin $\mathrm{i}$, and $b_{j}$ be the amount of the product required at destination $\mathrm{j}$. Further, we assume that the cost of shipping a unit amount of the product from origin i to destination $\mathrm{j}$ is $C_{i j}$ we then let $X_{\mathrm{i} j}$ represent the quantity of the product transported from origin $i$ to destination $\mathrm{j}$.

If shipping cost, are assumed to be proportional to the amount shipped from each origin to each destination so as to minimize total shipping cost turns out to be a linear programming problem.

Transportation models have wide applications in logistics and supply chain for reducing the cost. When the cost coefficients and the supply and demand quantities are known exactly, many algorithms have been developed for solving the transportation problem.

A considerable number of methods have been so far presented for finding an initial solution of a Transportation problem. It must be feasible i.e., it must satisfy all the supply and demand constraints. A solution is said to be feasible if $(m+n-1)$ cells [3] of the transportation matrix are allocated some units/items.

The cells having an allocation are known as 'Occupied cells' while, other cells are termed as 'Unoccupied cells'. The main concept of transportation is to establish the 'least cost route' problem is to find the optimum allocation of a number of resources to an equal number of demand points. An allocation plan is optimal if optimizes the total cost or effectiveness of transferring all the goods. This paper attempts to propose a method for finding optimal solution of transportation problem which is different from the preceding methods.

\section{Related Works}

This is work is alternative for existing MODI (Modified Distribution Method) method [3] in which the number of iteration is minimized. The optimal solution is coincide with the MODI method. It is also applicable for unbalanced [4] transportation problems.

Mathematical Formulation Of Transportation Problem

Mathematically a transportation problem can be stated as follows:

Minimize $Z=\sum_{i=1}^{m} \sum_{j=1}^{m} c_{i j} x_{i j}$ 


\section{A New Approach For Solving Transportation Problem}

This section presents a new method to solve the transportation problem which is different from the preceding method. We call it "Revised Distribution Method", because of making allocation by minimum demand and supply.

Step (i) Start with the minimum value in the supply column and demand row. If tie occurs, then select the demand or supply value with least cost [7].

Step (ii) Compare the figure of available supply (capacity) in the row and demand in the column and allocate the units equal to capacity or demand whichever is less.

Step (iii) If the demand in the column is satisfied, move to the next minimum value in the Demand row and supply column.

Step (iv) Repeat Steps (ii) and (iii) until capacity condition of all the plants demand conditions of all ware houses have been satisfied.

\section{Mathematical Concept Of The Subject}

One of the operations associated with matrices is calculation of scalar value known as the determinant of a square matrix [6]. Here we do not want calculate the determinant of a matrix, only we want to use the properties of the determinant operator, when we use customary and common notation, for the determinant of the matrix.

\section{Numerical Examples}

The following examples may be helpful to clarify the proposed method (Table 1):

\begin{tabular}{|c|c|c|c|c|c|c|c|c|c|}
\hline \multirow{3}{*}{$\begin{array}{c}\text { Plants } \\
\text { (i) } \\
1\end{array}$} & \multicolumn{8}{|c|}{ Warehouse (i) } & \multirow{3}{*}{$\frac{\text { Supplo }(0)}{\boldsymbol{S}_{\boldsymbol{1}}}$} \\
\hline & \multicolumn{2}{|c|}{$I$} & \multicolumn{2}{|c|}{2} & \multicolumn{2}{|c|}{$\ldots}$. & \multicolumn{2}{|l|}{$n$} & \\
\hline & $x_{\mu}$ & $c_{11}$ & $X_{12}$ & $c_{21}$ & - & $\ldots$ & $x_{1 n}$ & $c_{1 n}$ & \\
\hline 2 & $x_{t i}$ & $c_{21}$ & $x_{22}$ & $c_{22}$ & & ... & $x_{2 n}$ & $C_{2 n}$ & $S_{2}$ \\
\hline . & & $=$ & - & ... & - & - & - & $\ldots$ & w. \\
\hline$m$ & $x_{n 1}$ & $c_{m 2}$ & $X_{m z}$ & $c_{m 2}$ & & & $X_{\min }$ & $C_{m e g}$ & $S_{m}$ \\
\hline Demand & $D$ & & $D$ & & . & & $D_{n}$ & & \\
\hline
\end{tabular}

Table 1 Transportation Matrix.

Example 1: Consider the following transportation problem. Find most economical shipment to Minimize the transportation cost. So, we have the following transportation problem (Table 2).

In the table 3 the minimum value in the demand row and capacity column is 30 . The cell which is having least transportation cost in the $\mathrm{R}^{\text {th }}$ column is AR. Hence allocate the entire 30 units to this cell. It is (cell AR) ignored for the next iteration. The revised values of the table $-\mathrm{I}$ are indicated in the table-II. The occupied cell value is $(30 \times 6=180)$

\begin{tabular}{|c|c|c|c|c|}
\hline \multirow{2}{*}{$\begin{array}{c}\text { From } / \text { To } \\
\text { Plants }\end{array}$} & \multicolumn{3}{|c|}{ Warehouse(j) } & \multirow{2}{*}{ Capacity } \\
\hline & $P$ & $Q$ & $\boldsymbol{R}$ & \\
\hline$A$ & 11 & 9 & 6 & 40 \\
\hline$B$ & 12 & 14 & 11 & 50 \\
\hline$C$ & 10 & 8 & 10 & 40 \\
\hline Demand & 55 & 45 & 30 & 130 \\
\hline
\end{tabular}

Table 2 Transportation Matrix of the given balanced problem. 


\begin{tabular}{|c|c|c|c|c|c|}
\hline \multirow{2}{*}{$\begin{array}{c}\text { From } / T o \\
\text { Plants }\end{array}$} & \multicolumn{4}{|c|}{ Warehouse(j) } & \multirow{2}{*}{ Capaciyy } \\
\hline & $P$ & $Q$ & $R$ & & \\
\hline$A$ & 11 & 9 & 30 & 6 & 40 \\
\hline$B$ & 12 & 14 & $\uparrow$ & 11 & 50 \\
\hline$C$ & 10 & 8 & & 10 & 40 \\
\hline Demand & 55 & 45 & 30 & & 130 \\
\hline
\end{tabular}

Table 3 First allocation of the Transportation Matrix

In the table 4 the minimum value in the demand row and capacity column is 10 . The cell which is having least transportation cost in the $\mathrm{A}^{\text {th }}$ Row is AQ. Hence allocate the entire 10 units to this cell. It is (cell AQ) ignored for the next iteration. The revised values of the table -II are indicated in the table-III. The occupied cell value is $(\mathbf{1 0} \times \mathbf{9}=\mathbf{9 0})$

Table 4 Second allocation of the Transportation Matrix

\begin{tabular}{|c|c|c|c|c|}
\hline \multirow{2}{*}{$\begin{array}{c}\text { From } / \text { To } \\
\text { Plants }\end{array}$} & \multicolumn{3}{|c|}{ Warehouse(j) } & Capacüy \\
\hline & $\boldsymbol{P}$ & \multicolumn{2}{|c|}{$Q$} & \\
\hline$A$ & 11 & & 9 & 10 \\
\hline$B$ & 12 & 个 & 14 & 50 \\
\hline$C$ & 10 & & 8 & 40 \\
\hline Demand & 55 & 45 & & 100 \\
\hline
\end{tabular}

In the table 5 the minimum value in the demand row and capacity column is 35 . The cell which is having least transportation cost in the $\mathrm{Q}^{\text {th }}$ Column is CQ. Hence allocate the entire 35 units to this cell. It is (cell CQ) ignored for the next iteration. The revised values of the table -II are indicated in the table-III. The occupied cell value is $(\mathbf{3 5} \times \mathbf{8}=\mathbf{2 8 0})$

\begin{tabular}{|c|c|c|c|c|}
\hline \multirow{2}{*}{$\begin{array}{c}\text { From } 1 \text { To } \\
\text { Plants }\end{array}$} & \multicolumn{3}{|c|}{ Warehouse(j) } & \multirow{2}{*}{ Capacity } \\
\hline & $P$ & c & & \\
\hline$B$ & 12 & & 14 & 50 \\
\hline$C$ & 10 & 35 & 8 & 40 \\
\hline Demand & 55 & 3 & & 100 \\
\hline
\end{tabular}

Table 5 Third allocation of the Transportation Matrix

Table 6 Fourth allocation of the Transportation Matrix

\begin{tabular}{|c|r|r|c|}
\hline \multirow{2}{*}{$\begin{array}{c}\text { From } \\
\text { Plants }\end{array}$} & $\begin{array}{c}\text { Ware } \\
\text { house(j) }\end{array}$ & \multirow{2}{*}{ Capacity } \\
\cline { 2 - 2 } & \multicolumn{2}{|c|}{$\boldsymbol{P}$} & \\
\hline B & & 12 & 50 \\
\hline C & $\mathbf{5}$ & 10 & 5 \\
\hline Demand & 55 & 55 \\
\hline
\end{tabular}


In the table 6 the minimum value in the demand row and capacity column is 5 . The cell which is having least transportation cost in the $\mathrm{C}^{\text {th }}$ Row is CP. Hence allocate the entire 5 units to this cell. It is (cell CP) ignored for the next iteration. The revised values of the table $-\mathrm{II}$ are indicated in the table-III. The occupied cell value is $(\mathbf{5} \times \mathbf{1 0}=\mathbf{5 0})$

In the table 7 the remaining value in the demand row and capacity column is 12 . The cell which is having least transportation cost in the $\mathrm{B}^{\text {th }}$ Row is BP. Hence allocate the entire 50 units to this cell. The occupied cell value is $(\mathbf{5 0} \times \mathbf{1 2}=\mathbf{6 0 0})$

Optimal Solution $\quad(30 \times 6)+(10 \times 10)+(35 \times$ Fsqu8 $)+(10 \times 5)+(50 \times 12)=1200$

The transportation cost $=(5 \times 11)+(5 \times 9)+(30 \times 6)+(50 \times 12)+(40 \times 8)=1200$

Existing One MODI Method Initial Solution by NWCM

Net cost change for all water square is positive.

\begin{tabular}{|c|r|r|c|}
\hline \multirow{2}{*}{$\begin{array}{c}\text { From/To } \\
\text { Plants }\end{array}$} & \multicolumn{1}{|c|}{$\begin{array}{c}\text { Ware } \\
\text { house(j) }\end{array}$} & \multirow{2}{*}{$\begin{array}{c}\text { Capaci } \\
\text { ty }\end{array}$} \\
\cline { 2 - 3 } & \multicolumn{2}{|c|}{$P$} & \\
\hline B & 50 & 12 & 50 \\
\hline Demand & 50 & & 50 \\
\hline
\end{tabular}

Table 7 Fifth allocation of the Transportation Matrix

\begin{tabular}{|c|c|c|c|c|c|c|c|}
\hline \multirow{3}{*}{$\begin{array}{c}\text { From } / \text { To } \\
\text { Plants } \\
A\end{array}$} & \multicolumn{6}{|c|}{ Warehouse(j) } & \multirow{3}{*}{$\begin{array}{c}\text { Capacity } \\
40\end{array}$} \\
\hline & \multicolumn{2}{|c|}{$\boldsymbol{P}$} & \multicolumn{2}{|l|}{$Q$} & \multicolumn{2}{|c|}{$\boldsymbol{R}$} & \\
\hline & 40 & 11 & & 9 & & 6 & \\
\hline $\boldsymbol{B}$ & 15 & 12 & 35 & 14 & & 11 & 50 \\
\hline$C$ & & 10 & & 8 & 30 & 10 & 40 \\
\hline Demand & 5 & & 45 & & 3 & & 130 \\
\hline
\end{tabular}

Table 8 Transportation Matrix NWCM

\begin{tabular}{|c|c|c|c|c|c|c|c|}
\hline \multirow{3}{*}{$\begin{array}{c}\begin{array}{c}\text { From/To } \\
\text { Plants }\end{array} \\
A\end{array}$} & \multicolumn{6}{|c|}{ Warehouse (j) } & \multirow{3}{*}{$\begin{array}{c}\text { Capacity } \\
40\end{array}$} \\
\hline & \multicolumn{2}{|c|}{$P$} & \multicolumn{2}{|c|}{$Q$} & \multicolumn{2}{|c|}{$\boldsymbol{R}$} & \\
\hline & 5 & 11 & 5 & 9 & 30 & 6 & \\
\hline $\boldsymbol{B}$ & so & 12 & & 14 & & 11 & 50 \\
\hline c & & 10 & 40 & 8 & & 10 & 40 \\
\hline Demand & \multicolumn{2}{|c|}{55} & \multicolumn{2}{|c|}{45} & \multicolumn{2}{|c|}{30} & 130 \\
\hline
\end{tabular}

Table 9 Optimal Transportation Matrix of MODI

\section{Conclusion}

In this paper, a new and simple method was introduced for solving transportation problem. This method can be used for all kinds of transportation problems, whether maximize or minimize objective function. This new method is based on the allocation of demand and supply items in the transportation matrix, and finds an optimal solution in terms of the ones.

\section{References}

[1] M. S. Bazarra, John J. Jarvis, Hanif D. Sherali, Linear programming and network flows, (2005).

[2] B. s. Goel, S. K. Mittal, Operations Research, Fifth Ed., (1982) 2405-2416.

[3] Hamdy A. Taha, Operations Research, an introduction, 8th Ed. (2007).

[4] H. J. Zimmermann, Fuzzy set theory and its Applications, third Ed., Kluwer Academic, Boston, 1996.

[5] Anshuman Sahu, Rudrajit Tapador, Solving the assignment problem using genetic algorithm and simulated annealing, IJAM, (2007).

[6] Shayle R. Searle, Matrix algebra useful for statistics, John Wiley, (2006).

[7] Ones Assignment Method for Solving Assignment Problems Hadi Basirzadeh Applied Mathematical Sciences, Vol. 6, 2012, no. 47, $2345-2355$ 